\title{
Social Media, Public Sphere and Movement Discussion of Urban Farming in Indonesia
}

\author{
Stepanus Bo'do' ${ }^{1}$, Hotman Siahaan ${ }^{2}$, Rachmah Ida ${ }^{3}$ \\ ${ }^{1,2,3}$ Airlangga University \\ swilfrid2@yahoo.co.id
}

\begin{abstract}
The internet and social media expand public sphere has been much associated with public sphere and digital networks in many studies, where Habermas's public sphere theory and the theory of the Castells network society have been much debated about its relevance to the techno-social development. Both Habermas and Castells tend to see the public sphere of the Internet as a contestation space where corporate and state forces work in various ways to control and dominate it. This study emphasizes more on the creativity of citizens forming community networks through the use of the Internet and social media and conducting autonomous conversations in the public sphere. Netnographic studies of the dynamics of the discourse of public sphere in the social movement networked Indonesia Berkebun show that the Internet and social media become creative means for citizens to package global discourse locally to voice their demands. This study concludes that the concepts and theories of public sphere, network society are relevant as tools for analyzing public sphere and Internet networks and social media. The potential of the Internet network and social media as autonomous communication spaces depends on the design and purpose and the utilization of available features. Conversations that are restricted to the agenda of the $3 E$ program help communities focus on discourse and shape the character of a rational Indonesian gardening space. This community from the beginning realized the potential of the Internet and social media to form networks and public spheres. But like gardening, public sphere requires commitment, such as caring for the garden from pest attacks, weeds, giving it fertilizer so the plants grow as expected.
\end{abstract}

Keywords : public spheres, community networks, networks, urban farming, networking social movements

\section{Introduction}

The internet and social media are seen as having the potential to expand public sphere, territory or domain where discourse takes place involving citizens openly. However, the existence of the Internet public sphere tends to be seen as a contestation space where corporate and state forces try with various ways to control and dominate it. Nevertheless, the wave of digital activism has become a creative means for citizens to develop global and local discourses. They use social media as an alternative to creating autonomous public sphere, and consolidate counter power against other forces (state / corporation).

In Indonesia, one of the discourses developed by citizens through digital activism is the urban farming by the Indonesian Berkebun community. Starting from lectures on urban farming by Ridwan Kamil, a well-known lecturer and architect in Jakarta in the latter part of 2010, the community activists of gardening activities in urban farmers that were initially limited in Jakarta developed in a number of cities to become networks of communities that named yourself Indonesia Berkebun. Currently, Indonesia Berkebun is at the forefront of the discourse on urban farming in Indonesia.

The concept of urban farming has become popular in many cities in the world. Urban farming is considered a means of promoting public health and economic development, building social capital, and reusing vacant land in urban areas. In recent years, cities in America such as 
Detroit, San Francisco and Washington DC have prepared programs to encourage citizens to plant crops on vacant land or on rooftops. ${ }^{1}$

There are two social movements that are often used as the topic of study and the reference to the success of social media movements in creating citizen digital activism in Indonesia, namely "Coins for Prita" and "Cases of Lizards vs. Crocodiles" (Lim, 2014). However, in recent years, there is a wave of new types of activism that is different from the social movements and campaigns that we are familiar with, namely 'quiet digital activism' (silent activism). ${ }^{2}$ This silent digital activism also utilizes newer technologies and finds new strategies for organizing social and economic life. This new type of digital activism also seeks to change society more directly by giving individuals the ability to work and collaborate without depending on government or company infrastructure (Karatzogianni, 2016).

Athina Karatzogianni stressed that aside from the political movements that we have known for the past two decades, a new form of digital activism has emerged, namely 'quiet digital activism' (silent digital activism). ${ }^{3}$ There are two quiet digital digital activism patterns. First, activism that focuses on preparing a platform for social movements. This type of activism in Indonesia, among others, is carried out by the Kitabisa community or Indorelawan. Kitabisa is the most popular online crowdfunding and fundraising platform in Indonesia. The latest action is trusted to raise funds for the R80 aircraft project (Kitabisa, 2018). ${ }^{4}$ Indorelawan is an online forum that makes collaboration between volunteers and organizations / social communities easier. Through this site, social organizations / communities can create activities to find volunteers as needed and manage volunteers. As well, volunteers can choose activities according to their interests, location and time. ${ }^{5}$

Second, digital activism which focuses on providing alternative solutions for the community. The Indonesian berkebun Community can be included in this second category. The urban farming movement carried by Indonesia Berkebun is an alternative for residents in urban areas to overcome the problems of environmental crisis (ecology), food security (economy), and gardening knowledge (education).

All forms of digital activism are basically designed to force change by putting political pressure on leaders and other powerful groups. However, the new types of digital activity above also seek to change society more directly by giving individuals the ability to work and collaborate without depending on government or company infrastructure. For them, the Internet will always make it possible to form new communities and share resources. What distinguishes is how these communities make use of a set of ideological and practical tools, creating a cooperative platform to realize social change according to the agenda they are carrying out

\footnotetext{
1 "The real value of urban farming. (Hint: It's not always the food.) - Vox." 12 Oct. 2016, https://www.vox.com/2016/5/15/11660304/urban-farming-benefits. Accessed 9 Nov. 2018.

2 "Beyond hashtags: how a new wave of digital activists is changing society." 11 Apr. 2016, http://theconversation.com/beyond-hashtags-how-a-new-wave-of-digital-activists-is-changing-society-57502. Accessed 29 Oct. 2018.

${ }^{3}$ Athina Karatzogianni is a Senior Lecturer in Media and Communication at the University of Leicester, UK specializing in the linking of New Media theories with a network of resistance and global politics. Athina has reviewed the use of digital technology social movements, protest actions, and by rebel groups.

4 "Kitabisa! - Dukungan Indonesia Untuk R80." https://kitabisa.com/pesawatr80. Accessed 29 Oct. 2018.

5 "Indorelawan.org (@indorelawan)•Instagram photos and videos." https://www.instagram.com/indorelawan/?hl=en. Accessed 29 Oct. 2018.
} 
(Heryanto, 2018) ${ }^{6}$ (Karatzogianni, 2016). ${ }^{7}$ From this perspective, the Indonesia Berkebun community can become one strong group according to Ross Tapsell. ${ }^{8}$ Activists from Indonesia Berkebun are civil society groups who are familiar with cyberculture. They express anxiety by engaging in discourse on environmental issues (ecology), food security (economy) and awareness of independence (education). After reaching consensus in the public sphere of the Internet, they acted in the form of discourse and urban farming activities (communicative actions).

\section{Research Method}

Neutrographic methods have recently become increasingly popular among cultural researchers, especially in the fields of marketing, advertising and education. In Indonesia, this method has become known. Some undergraduate theses that can be accessed on the Internet, have used this method to study site-situ online communities.

In contrast to the ethnographic approach that emphasizes participatory approaches, where researchers are fully involved as members of online communities, the Neutrographic approach is closer to traditional ethnographic standards regarding participatory observation, long involvement, and immersing oneself deeply. Neutrographic retains the values of traditional ethnography by providing 'thick description' of Clifford Geertz through 'immersion' of researchers into cultural life or online communities. The focus on participation and immersion makes this approach quite different from analyzing the use of the web or social media networks, even though ethnographers might use similar techniques to identify network maps. ${ }^{9}$

Referring to the general ethnographic procedure, Kozinets recommends methodological stages and procedures for Neutrographic studies; entrée: includes the formulation of research questions and identification of the right online community for study. Data collection; includes copying of communication mediated by computers of community members and observations of the community and its members, the interactions and meanings they share. Analysis and interpretation; includes classification, coding analysis, contextualization of communicative actions.

There are three discourse mechanisms by Indonesia Berkebun which are analyzed to illustrate the dynamics of urban farming discourse, namely through Gardening, Conference and Collaboration. The dynamics of discourse on urban farming was developed using the coding base analysis method. The coding process is carried out by pinning code / categories on data from field notes, documents, including, materials posted on groups or web, Facebook, Twitter, Instagram and Line pages such as text, images, videos. The code is embedded in several keywords related to three categories, economic, economic and educational. Some reflection

\footnotetext{
6 "Budaya Populer di Indonesia, Mencairnya Identitas Pasca-Orde Baru ...." https://www.goodreads.com/book/show/15776985-budaya-populer-di-indonesia-mencairnya-identitas-pascaorde-baru. Accessed 29 Oct. 2018.

7 "Beyond hashtags: how a new wave of digital activists is changing society." 11 Apr. 2016, http://theconversation.com/beyond-hashtags-how-a-new-wave-of-digital-activists-is-changing-society-57502. Accessed 31 Oct. 2018.

8 "Book Review: Ross Tapsell: Media Power in Indonesia: Oligarchs ...." https://journals.sub.uni-hamburg.de/giga/jsaa/article/download/1094/1101. Accessed 30 Oct. 2018.

9 "(PDF) Using Netnography to Explore the Culture of Online Language ...." https://www.researchgate.net/publication/282964488 Using Netnography to Explore the Culture of . Online Language Teaching_Communities Accessed 4 Dec. 2018.
} 
notes on data or additional notes will be added to the analysis. By sorting materials and filtering to identify the same expressions, the same sequences, relationships, or striking differences and attract the attention of researchers.

Social media provides data on online communication and interaction in the Indonesia Berkebun community. From data on communication and interaction in Indonesia Berkebun's social media accounts, we can see the dynamics of 3E Indonesia Berkebun's discourse. To see the dynamics of this discourse, we use data from the Facebook Fanpage page which is also displayed in table form through the Netvizz application. This data shows upload material, words (status), links (links), images (photos) and videos. In the table, uploading sentences and fragments appear, which are topics related to the $3 \mathrm{E}$ discourse that get a more dominant reaction. Different colors show upload material, the size of the circle shows the popularity of getting reactions in the form of comments, emotions and shares from the members.

\section{Discussion}

\subsection{Dinamika Discourse 3E from Indonesia Berkebun}

Social media provides data on online communication and interaction in the Indonesian Berkebun community. To see the dynamics of this discourse, researchers used data from the Facebook Fanpage page. Using the Netvizz application, researchers retrieve the @ IDberkebun account data from October 2017 - October 2019. With the same application, data in the form of upload material, words (status), links (images), images (photos) and videos can be visualized in table form which illustrates the dynamics of the $3 \mathrm{E}$ discourse in the Indonesia Berkebun community.

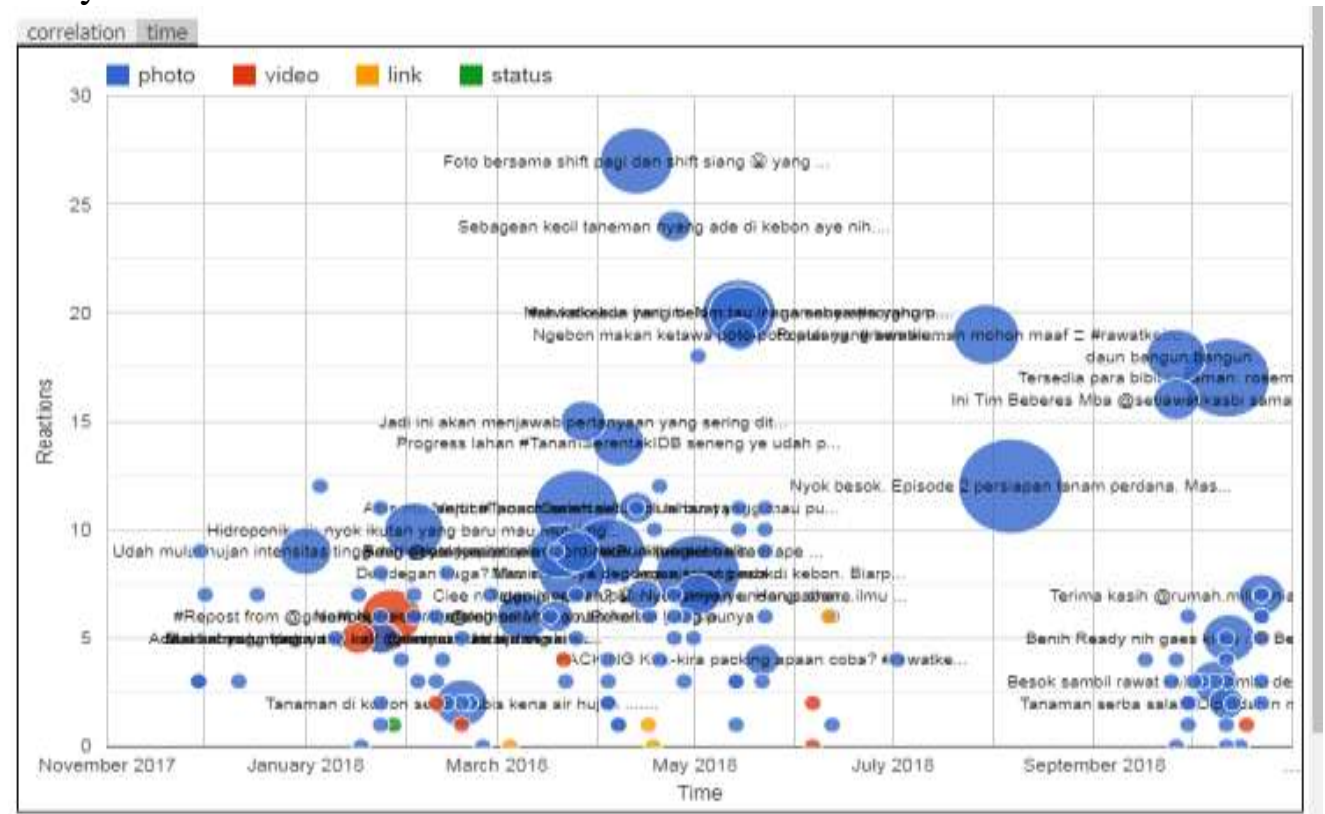

Now digging for reactions ( 841 ) and comments ( 123). Posts processed: 012345678910111213141516171819202122 2324252627282930313233.3435363738394041424344454647484950515253545556575859606162636465 66676869707172737475767778798081828384858687888990919293949596979899100101102103104105

Figure 1. Upload distribution and interaction

Facebook account@IDberkebun. 
Figure 1 illustrates the dynamics of $3 \mathrm{E}$ discourse. The dynamics can be seen in upload distribution and reaction to uploads. In this table, you can see the distribution of uploaded material displayed in a circle with color variations. The size of the circle represents the number of reactions to uploads. In clear visualization, the number of uploads tends to go up and down all the time. For example, most interactions occur in March-April 2018. Upload types also vary. For example, it is clear that the photo material is the most uploaded material throughout October 2017-October 2018.

In addition, The key sentence fragment is also displayed from the upload description. Sentences such as "urban farming are important for urbanites", "homes with roof gardens", easy ways to plant chili, "gardening academies" "farmers in the city of ngebon" are narratives developed by the Indonesian Berkebun community in the public sphere. The narrative of ecological discourse is associated with efforts to open garden land with the aim of restoring soil fertility and saving the environment and green open spaces that are open to all residents of the city.

The economic discourse narrative is associated with efforts to create sustainable city food security. Educational discourse is narrated as an effort to provide public education especially to future generations (children) to love the environment. These narratives can be categorized into 3E discourse. For example, the sentence, "Nyok tomorrow episode 2 of the initial planting preparation," is included in the ecological category, because it is related to the ritual activity \#tanamperdana. The sentence, "so this will answer the questions that are often asked ..." categorized as educational discourse because it is related to question and answer aimed at public education.

They claim that through the urban farming program, that is utilizing sleeping and critical land in urban areas to become productive agricultural / plantation land can be a solution to the environmental crisis and future food crisis. This program will help overcome environmental problems such as the increasingly lack of green open space, the threat of flooding in cities. By involving the community at large, they can achieve sustainable food independence and educate the younger generation to love the environment more.

The Indonesian Berkebun community started from lectures on Twitter by Ridwan Kamil about urban farming in the latter half of 2010. These lectures on urban farming are a discourse that attracts attention on social media. A group of people began discussing the idea of urban farming for the City of Jakarta. The discussion was followed up through meetings and plans to form a community that carries the idea of urban farming. The group held its first meeting in October 2010.

In the beginingJanuary 2011, an email and Twitter account was created @Jktberkebun after agreeing to a name branding, namely Jakarta Berkebun-@Jktberkebun. The initial plant was conducted on February 20, 2011 involving 150 people from various backgrounds and professions. The first successful planting, echoed on social media, especially on Twitter.

In March 2011, through initial planting in the cities of Bogor and Bandung, marking the birth of Indonesia Berkebun. Until now, Indonesia Berkebun has a network in several major cities in Indonesia. Starting from Twitter, this community develops on Facebook, Instagram and coordinates through the LINE application. Within 4 years, Indonesia Berkebun has spread in 33 cities and 9 campuses throughout Indonesia

Through its movement, Indonesia Berkebun has been awarded by Google Asia Pacific for the Web-Heroes category in 2012, Inspiring Movement for Environment 2013, and Nutrifood Finalist for the 2013 Ashoka Changemakers, World Summit Youth Award for the 
Go Green category, and other appreciation from national media and internationally as well as private and government agencies.

Planning of urban farming Indonesia Berkebun is closely related to global discourse about it. Ridwan Kamil's Twitter lectures on urban farming which became the forerunner of the formation of the Indonesian Berkebun community movement took place since the first half of 2010. These lectures were not long after urban farming became a global topic, which has become increasingly popular since the emergence of vegetable gardens in the White House yard in the United States at the initiative of first lady Michelle Obama at that time. The opening ceremony of the organic vegetable garden in the White House took place on Friday, March 20, 2009 and was covered by a lot of media. In August 2012, Michelle Obama published a gardening guidebook entitled American Grown. In the book he wrote down his belief that gardeners "bring individuals and communities together." 10

Michelle Obama's activities are organic gardening in the White House and promote the rise of community gardens. The Telegraph newspaper published in the UK called Michelle Obama's gardening ${ }^{11}$ activities won the hearts of Americans (wins America's hearts) ${ }^{12}$ won the hearts of Americans) while angering agricultural companies. ${ }^{13}$

Michelle Obama's initiative brought people to recall how victory garden had been so popular in America during World War II. At that time, millions of Americans planted a variety of plants in 'victory gardens' on their yard, which eventually succeeded in supplying 40 percent of fruit and vegetables to a starving nation. Once the war was over, the gardens withered, replaced by agriculture in rural areas on a large scale.

Raychel Santo et al from Johns Hopkins ${ }^{14}$ in a report entitled Vacant lots to vibrant plots: A review of the benefits and limitations of urban agriculture provides an overview of documented socio-cultural, health, environmental and economic impacts of the urban farming program. They also discussed the impacts and potential benefits, as well as the risks and limitations, of this growing urban farming, and offered recommendations for further research to strengthen urban farming studies. ${ }^{15}$

Indonesia Berkebun seems to take inspiration from Washington. Ridwan Kamil's Twitter lectures on urban farming which became the forerunner of the formation of the Indonesia Berkebun community movement took place since the first half of 2010. These lectures were not long after urban farming became a global topic, which has become increasingly popular

\footnotetext{
10 "Michelle Obama champions vegetable gardens and healthy food in ...." 2 Aug. 2012, https://www.washingtonpost.com/lifestyle/style/michelle-obama-champions-vegetable-gardens-and-healthyfood-in-american-grown/2012/08/02/gJQAYrBvSX_story.html. Accessed 12 Nov. 2018.

11 "First Lady Surprise! - Urban Farm Plans." 3 Mar. 2016, http://www.urbanfarmplans.com/first-lady-surprise/. Accessed 9 Nov. 2018.

12 "Michelle Obama's organic garden wins America's hearts | LifeGate." 24 Sep. 2015, https://www.lifegate.com/people/lifestyle/michelle-obama-organic-garden. Accessed 9 Nov. 2018.

13 "Michelle Obama's organic garden angers US farming companies ...." 23 Apr. 2009, https://www.telegraph.co.uk/news/worldnews/michelle-obama/5204434/Michelle-Obamas-organic-gardenangers-US-farming-companies.html . Accessed 9 Nov. 2018.

14 "(PDF) Vacant lots to vibrant plots: A review of the benefits and ...." https://www.researchgate.net/publication/319213554_Vacant lots to vibrant_plots_A review of the benefit and limitations of urban agriculture Accessed 9 Nov. 2018.

15 "(PDF) Vacant lots to vibrant plots: A review of the benefits and ...." https://www.researchgate.net/publication/319213554_Vacant_lots to vibrant_plots_A_review_of the benefit_and_limitations_of_urban_agriculture. Accessed 9 Nov. 2018.
} 
since the emergence of vegetable gardens in the White House yard in the United States at the initiative of first lady Michelle Obama. The family activities of the White House residents in the small garden amaze the citizens of the world through photos that are viral on social media.

Ridwan Kamil's dream of what happened in America inspired him to take the initiative to make a discourse about urban farming to middle-class urbanites in Indonesia, while at the same time inviting and arousing their awareness to follow the initiative he had initiated. This awareness was then captured by urban middle class individuals who began to dock and become part of running the urban farming initiative, not as a form of movement in Havana or Michel Obama's movement to win the America's hearts, but a new awareness movement and part of the trend towards new lifestyles of urban middle class residents eating quality vegetables from the gardens they built themselves. Including awareness of the dilemmatic urban environment. This is a form of silent movement or activism carried out in virtual spaces and special spaces of community farming and urban farming activists.

On the other hand, this discourse can be read as part of Ridwan Kamil's effort to "win the hearts" of the citizens of Bandung and its surroundings. Later, Ridwan Kamil really won the hearts of the people of Bandung and West Java, until he was elected Mayor of Bandung and then the current Governor of West Java. This silent and actual virtual activism has been able to become a power to lift the image and popularity of Ridwan Kamil to the middle class Bandung and middle-class Millenials in the city. Moreover, the issues related to the environmental crisis and global warming are classified as "elite" issues for most Indonesian people who are not aware of this problem, except for the educated, and a certain portion of the urban middle class in the big cities of Indonesia. Many cities in the world are encouraged to be involved in urban farming programs and policies. This is said to be a means to promote public health and economic development, build social capital, and reuse land that is not used. Various advocacy groups that try to incorporate urban farming into policy design often struggle with how to frame the benefits and potential problems in urban agriculture efforts.

While it is still debated whether the urban farming program makes sense, are there real environmental and social impacts on gardening in urban areas? This is also a dilemma discourse in Indonesia. Concern and awareness of a group of communities in certain urban areas in Indonesia trying to create this discourse is part of political and development talks in urban areas in elite public spheres such as universities and environmentally conscious communities and urban architecture. Unfortunately, this idea did not get a massive response from most or a majority of city residents who were busy dealing with life dilemmas such as urban poverty, slums, construction of new apartments, and other complicated problems in the city.

\subsection{Indonesia Berkebun as a Campaign and Silent Urbanities Activism of Indonesian}

So far 3 main mechanisms of campaign have been used by Indonesia Berkebun so that their $3 \mathrm{E}$ discourse remains a conversation in the public sphere. The three mechanisms can be summarized in three key words: Gardens, Conferences and Collaboration (3K). These three mechanisms have agendas and activities which in turn shape the dynamics displayed in the above visualization through the agenda of Indonesia Berkebun. Such dynamics are an illustration of the extent to which the activity agendas in all networking communities are ongoing and continuous or stop altogether. It is easily duplicated by the community, the $3 \mathrm{E}$ discourse and the $4 \mathrm{E}$ Mechanism developed by Indonesia Berkebun have the opportunity to continue to develop in the future as a campaign and silent activism of urbanites. 
In Indonesia, environmental issues are often considered sensitive and avoided being discussed publicly because they usually disrupt corporate interests. This also has an impact on the public perception of the urban farming campaign. This activism has never emerged as a popular movement such as the action of Koin Prita or Lizard Vs Crocodile. Indonesian Berkebun Activism has become a silent activism that prioritizes the interest of the urban middle class to campaign for the ideas of leisure and pleasure with a new lifestyle. As a typical activism of the urban middle class, in their gardening activities, smartphones play more roles than hoes. Uploading to social media via smart devices (smartphones) takes precedence over hoe swings. Interaction on social media is still greater than gardening activities. In 6 years, Jakarta Berkebun only has five gardening locations. The Makassar gardening community currently only manages one garden measuring only the size of a tennis court.

The activists involved are not familiar with farming activities that squeeze energy and sweat. That's why in their uploads they still look fashionable in the garden area. In addition, the activity in the garden is more directed as an activity of leisure and pleasure. More importantly, scientific discussions about urban farming. So that the activists seem to be an exclusive utopian group compared to city farmers who are really potential to protect the city from the future environmental crisis.

However, the urban middle class that drives Indonesia Berkebun is at the same time a digital citizenry that craves change by developing the ability to work and collaborate, autonomously outside the infrastructure managed by the government or corporation. A number of awards from various institutions accepted by this community can be an indication of their influence as a citizenry digital community (Tapsell, 2018). This is in line with the conclusions of the study (van der Laarse, 2016) which shows that even though it is generally in the form of a non-political movement, the environmental movement in Indonesia is one of the strongest social movements, and is believed to be influential not only in the environment. but also at the social, economic and political levels. Indonesia Berkebun has become part of digital citizenry which Ross Tapsell calls a strong group that is able to compensate for challenging elite power structures operating in digital media.

Despite a silent movement, Indonesia Berkebun proved to get attention and even gave birth to political figures in this country. At the time of the first Indonesia Berkebun Conference held in Solo in November 2011, Joko Widodo, Mayor of Solo, who was rising in popularity at the time, attended the conference. Events were covered by the media widely. Of course, in the eyes of politics, Joko Widodo's decision to open a conference would have to be calculated. However, urban farming discourse campaigned by community networks signals what is being loved by the community. One year later, we learned that the two periods of Solo mayor were elected as the Governor of DKI Jakarta in 2012-2014. Because of his popularity, the governor with the popular name Jokowi is advanced and was elected President of the Republic of Indonesia in the 2014 election. Jokowi is not only able to read sensitive alarms in online discourse activism, but was also able to use it to support it. Digital volunteers supporting Jokowi in the 2014 Pilgub and Pilpres were described as social media activists.

Indonesian Berkebun's Initiator, Ridwan Kamil, also enjoyed media coverage. "Indonesia Berkebun has a vision and mission ahead in creating more productive green land in urban areas. Later, it is hoped that the green land can be used as educational material for citizens to love nature and the environment as well as maintain the food security of urban communities. Two years later Ridwan Kamil as the founder of Indonesia Berkebun as a candidate by the Gerindra party and PKS and was elected in the Bandung mayor's election. In the general 
election of the West Java Governor of 2018, Ridwan Kamil was promoted by PPP, the National Awakening Party (PKB), the Nasdem Party, and the Hanura Party. Ridwan Kamil was elected Governor of West Java for the period 2018-2023. Although not directly linking the Indonesian movement to the emergence of Ridwan Kamil as Mayor of Bandung, the study of Muhammad Iqbal shows that the movement that promotes the concept of urban farming in the city received many positive reviews because it has encouraged people to grow their own food. Some national media gave positive reviews of their innovations. Its popularity has also received international attention. An article in Globe Asia reports that Kamil's dedication to the art of happiness and community collaboration earned him praise and loyal followers in the political system plagued by corruption (Tisdanibrata, 2015 in Iqbal, M). The Financial Times even quoted Kamil as the new face of Indonesian politics (Bland, 2013 in Iqbal, M).

Public sphere according to Habermas is a region (space) where citizens express their opinions and needs discursively. Ideally, the public sphere must be accessible to everyone, free, open and transparent and there is no state and market intervention in it. The existence of an autonomous space (hybrid space) between digital space and urban space where autonomous communication takes place, according to Manuel Castells is the essence of networking social movements. It is this autonomous communication space that shapes the movement, and enables it to connect with society at large beyond authority control over the flow of communication (Castells, 2015). The Indonesian gardening activism brings together the concept of Habermas's public sphere with the autonomous space of Castells communication.

The Indonesian Berkebun urban farming movement was chosen as the topic of this research mainly because it indicated a shift in public sphere discussions to non-political areas such as the architectural region. In addition, by questioning the steps of green open spaces, city parks, Indonesia Berkebun is actually questioning the existence of threatened communication places. In this sense, the town square, like the HI roundabout, which is often the place for various expressions of protest and initiative of the people, is the space that remains for the citizens who are increasingly squeezed in urban areas. The issue of increasingly squeezed communication space is described by Jurgen Habermas as a process of reformalization of public sphere and system colonization of the life world of civil society (Habermas, 1981).

The conception of public sphere by the Indonesian Berkebun community is closely related to the architectural perspective and reinforces the claim that the development of information and communication technology must be seen culturally that it has a major impact on the democratic participation of citizens so as to contribute to expanding public sphere. This research is expected to add to the discussion of aspects of culture about public sphere that extends to non-political areas such as the area of art and architecture (Hardiman, 2010).

One of the characteristics of the Indonesia Berkebun movement is that this movement appears in urban areas carrying discourse and urban farming ideas that are tailored to the needs and lifestyles of urban communities. This movement is a place to express the hopes and anxieties of urban residents towards conditions of environmental crisis and food dependence in urban areas. This problem is faced by urban society globally. Globalization has been blamed for eliminating the ability of the people in their own food production, resulting in the inability to overcome food injustice.

Urban farming ${ }^{16}$ is an increasingly popular issue in various parts of the world because of its potential which is considered to be one of the creative ways to overcome ecological

16 "Urban Agriculture and the Future of Farming in the United States." 
problems in urban areas and reduce dependence on the surrounding area (Naidoo, 2018). ${ }^{17} \mathrm{~A}$ study in the United States has shown that cities can actually meet up to $100 \%$ of fresh product needs. This will prevent up to $\$ 115$ million in annual economic leaks. If using rooftop spaces in New York City will be able to provide about twice the amount of space needed to supply the city with green vegetables. Rooftop can be better optimized through the use of hydroponic production or indoor food. The existence of gardens in cities will also reduce the amount of food waste. To finance these projects, financial capital is needed in the form of private companies or government funding.

\section{Conclusion}

Although, urban farming discourse by the Indonesia Berkebun movement is closely related to the global discourse on urban farming that is associated with economic, social and environmental potential, it is associated with the demands of public spheres and green open spaces in urban areas.

Communication and interaction through official Indonesian Berkebun accounts and their networks on various social media platforms analyzed form the network structure of Indonesia Gardening and enable their movements to shape ecological, economic and educational discourse (3E) significantly in the public sphere and connect urban farming and networking discourse they are with local and global actors.

Gardening activities validate ecological, economic and educational discourse claims on various Indonesian Berkebun's social media accounts. The community is quite successful in focusing on rational discourse accompanied by claims and validation and avoids their public sphere from utterances of hatred. However, the success of caring for public spheres is not always in line with the success of caring for their gardens. This community still needs to balance the hoe swing by uploading it to social media through their smart devices.

\section{References}

Castells, M. (1996). The Rise of the Network Society. Oxford: Blackwel.

Castells, M. (2009). Communication Power. New York: Oxford University Press.

Castells, M. (2004). End of Millennium. Oxford: Blackwell.

Castells, M. (2004b). The Power of Identity. Oxford: Blackwell.

Castells, M. (2008). The New Public Sphere: Global Civil Society, Communication Networks, and Global Governance. The ANNALS of the American Academy of Political and Social Science, 616 (1), 78-93.

Castells, M. (2015). Network of Outrage and Hope, Social Movement in the Internet Age, Polity Press. Cambridge, UK: Polity Press.

Castells, M. (2014, September 8). The Impact of the Internet on Socity: A Global Perspective. Retrieved Maret 10, 2018, from BBVA Open Mind:

\footnotetext{
https://soa.utexas.- edu/sites/default/disk/munich_papers/munich_papers/10_02_su_calhoun_ana.pdf. Accessed 1 Nov. 2018.

17 "Urban agriculture is the key to a sustainable future | Food | Al Jazeera." 2 Mar. 2018, https://www.aljazeera.com/indepth/opinion/urban-agriculture-key-sustainable-future-180228150046550.html. Accessed 30 Oct. 2018.
} 
https://www.bbvaopenmind.com/en/article/the-impact-of-the-internet-on-society-aglobal-perspective/?fullscreen=true

Castells, M. et al. "A Conversation with Manuel Castells." EScholarship, University of California, 11 Nov. 2014,escholarship.org/uc/Item/2ns059h3.

Dahlberg, Lincoln, James. The Internet and the Public Sphere: a Critical Analysis of the Possibility of Online Discourse Enhancing Deliberative Democracy: a Thesis Presented in Partial Fulfilment of the Requirements for the Degree of Doctor of Philosophy in Sociology at Massey University. 2000.

Direktorat Sistem dan Teknologi Informasi ITB. "Urban Farming Belum Jawab Ketahanan Pangan -." Institut Teknologi Bandung, www.itb.ac.id/news/read/4245/home/urbanfarming-belum-jawab-ketahanan-pangan.

Esbjornson, Carl D. "Once and Future Farming: Some Meditations on the Historical and Cultural Roots of Sustainable Agriculture in the United States." Agriculture and Human Values, vol. 9, no. 3, 1992, pp. 20-30., doi:10.1007/bf02217918.

Fuchs, Christian. "Social Media and the Public Sphere." TripleC: Communication, Capitalism \&amp; Critique. Open Access Journal for a Global Sustainable Information Society, vol. 12, no. 1, 2014, pp. 57-101., doi:10.31269/vol12iss1pp57-101.

Fuchs, Christian. "Some Reflections on Manuel Castells' Book 'Communication Power."' TripleC: Communication, Capitalism \&amp; Critique. Open Access Journal for a Global Sustainable Information Society, vol. 7, no. 1, Jan. 1970, pp. 94-108., doi:10.31269/vol7iss1pp94-108.

Fultner. Jürgen Habermas: Key Concepts. Acumen, 2010.

GATRAcom. "Gatracom - RIDWAN KAMIL: Jaringan Kultwit Urban Farming." GATRA.com, www.gatra.com/rubrik/fokus-berita/22755-ridwan-kamil-jaringankultwit-urban-farming.

Habermas, J. "New Social Movements." Telos, vol. 1981, no. 49, Jan. 1981, pp. 33-37., doi: $10.3817 / 0981049033$.

Habermas, J. "New Social Movements." Telos, vol. 1981, no. 49, Jan. 1981, pp. 33-37., doi: 10.3817/0981049033.

Habermas Jürgen. Between Facts and Norms: Contributions to a Discourse Theory of Law and Democracy. Polity Press, 2012.

Habermas Jürgen. The Theory of Communicative Action. Reason and the Rationalization of Society. Polity Press, 1989.

Habermas Jürgen. The Structural Transformation of the Public Sphere: an Inquiry into a Category of Bourgeois Society. Polity, 2014.

Hardiman, F. Budi. Ruang Publik: Melacak 'Partisipasi Demokratis' Dari Polis Sampai Cyberspace. Kanisius, 2010.

Hardiman, Francisco Budi. Demokrasi Deliberatif: Menimbang Negara Hukum Dan Ruang Publik Dalam Teori Diskursus Jurgen Habermas. Penerbit Kanisius, 2009.

Hardiman, Francisco Budi. Empat Esai Etika Politik. Diterbitkan Oleh Www.srimulyani.net Bekerjasama Dengan Komunitas Salihara, 2011.

Hill, David T., and Krishna Sen. The Internet in Indonesia's New Democracy. Routledge, 2012. Kamil, M. Ridwan. Urban Farming Ala Indonesia Berkebun. PT. AgroMedia Pustaka, 2015.

Karatzogianni, Athina. "Beyond Hashtags: How a New Wave of Digital Activists Is Changing Society." The Conversation, 29 Aug. 2018, theconversation.com/beyond-hashtags-how- 
a-new-wave-of-digital-activists-is-changing-society-57502.

Lim, Merlyna. "Many Clicks but Little Sticks: Social Media Activism in Indonesia." Journal of Contemporary Asia, vol. 43, no. 4, 2013, pp. 636-657., doi:10.1080/ 00472336.2013. 769386.

Lim, Merlyna. "Many Clicks but Little Sticks: Social Media Activism in Indonesia." Journal of Contemporary Asia, vol. 43, no. 4, 2013, pp. 636-657., doi:10.1080/00472336.2013. 769386.

Naidoo, Indira. "Urban Agriculture Is the Key to a Sustainable Future." Food $\mid$ Al Jazeera, Al Jazeera, 2 Mar. 2018, www.aljazeera.com/ indepth/opinion /urban-agriculture-keysustainable-future-180228150046550.html.

Nugroho, Yanuar, and Sofie Shinta. Syarief. Beyond Click-Activism?: New Media and Political Processes in Contemporary Indonesia. Friedrich-Ebert-Stiftung, 2012

Paul, Mark. "Community-Supported Agriculture in the United States: Social, Ecological, and Economic Benefits to Farming." Journal of Agrarian Change, 2018, doi:10.1111/ joac. 12280 .

Pickerill, Jenny. Cyberprotest: Environmental Activism Online. Manchester University Press, 2010.

Pink, Sarah, et al. Digital Ethnography: Principles and Practice. Sage, 2016.

Safitri, Dini. "Perilaku PKS Lovers Di Media Sosial (Studi Netnografi Tindak Tutur PKS Lovers)." Jurnal Communicate, vol. 1, no. 2, 2017, p. 67., doi:10.31479/jc.v1i2.38.

Safitri, Dini. "Perilaku PKS Lovers Di Media Sosial (Studi Netnografi Tindak Tutur PKS Lovers)." Jurnal Communicate, vol. 1, no. 2, 2017, p. 67., doi:10.31479/jc.v1i2.38.

Seto, Ario. Netizenship, Activism and Online Community Transformation in Indonesia. Palgrave Macmillan, 2017.

Swartz, Haley, et al. "Promoting Sustainable Food System Change Amidst Inequity: A Case Study of Baltimore, Maryland." Advances in Food Security and Sustainability, 2018, doi:10.1016/bs.af2s.2018.09.006.

TAPSELL, ROSS. MEDIA POWER IN INDONESIA: Oligarchs, Citizens and the Digital Revolution. ROWMAN \&amp; LITTLEFIELD INTE, 2018. 